\title{
Science diary of a gifted student
}

\author{
Murat GENÇ \\ Faculty of Education, Bartin University, Turkey.
}

Accepted 8 March, 2013

\begin{abstract}
Learning processes of individuals in the education system have certain standards. Each individual is educated under the same conditions. Individual differences in the educational process are not taken into account in Turkey. These learning conditions do not vary from person to person. In this study, the lecture notes of a gifted student in (his) science classes are examined. The student was encouraged to keep a diary after his class for a whole semester. The student kept a diary about his Science and Technology classes and wrote down his opinions and what he had experienced during the classes. From the notes the student made, it is specified that the student followed science lessons in the first 15 min. In this 15 min period, the student was not eager to attend the lesson and speak. In the remaining time, he was engaged in what his friends were doing. Besides, he explored the equipment in the laboratory and observed the teacher.
\end{abstract}

Key words: Gifted student, active learning, attitude towards a course, elementary education, Science course.

\section{INTRODUCTION}

It is highly probable that around 2 to $3 \%$ of the existing student potential in a country is gifted (Gökdere and Çepni, 2003). Gifted students can be seen in rural areas as well as in urban areas. However, there are studies suggesting that the children of families with a strong economic and social background have higher opportunities to be recognized (Marland, 1972; Çepni and Gökdere, 2002).

Being gifted is defined as the combination of having a natural ability above the average, high levels of task commitment, and high levels of creativity. Gifted students should have all the three features. Gifted students have the afore-mentioned characteristics and a potential to develop them. These students need comprehensive educational opportunities that are not ordinarily provided through regular instructional programmes (Renzulli and Reis, 1985).

In the literature, the terms gifted children and children of superior intelligence are used in the same meaning. When we consider that both children have common characteristics in general, it is possible to see those words used to meet the same meaning. These children have different characteristics from the other individuals.
In a Maryland Report (1972) giftedness is defined as high performance and demonstrated achievement singly or in combination in one of the following areas (Passow, 1993):

a. General intellectual ability;

b. Specific academic aptitude;

c. Creative or productive thinking;

d. Leadership ability;

e. Visual and performing arts;

f. Psychomotor ability.

In order to use the talents efficiently, it is necessary to develop these talents in a systematic and programmed way. In general, gifted children need special conditions to improve their creative potential (Renzulli, 1999).

While talent is congenital, many researchers believe that it grows and develops by environmental factors. Parents, family circle, friends and social experiences strongly impact the development of children's skills (Culatta and Tompkins, 1999).

Students with these characteristics have a wide information storage capacity. They do not complain about the 
excessiveness of the information provided to them but rather remember and assimilate the information. They do these in a shorter period compared to their peers and this information they assimilated is more permanent compared to their peers. Not only they can comprehend sophisticated structures easily but also they can provide more than one alternative solutions since they can build the logical structure in a short period of time as a result of their improved creativity. These suggestions are original and cleverly designed (Ataman, 1996).

Although these students are almost two years ahead of their peers in terms of school success, such differences bring along problems in these students' education. These students might not be accepted to some social circles since they show leadership characteristics. They might have problems with their friends since they vigorously support their ideas and have a subtle sense of humor (Ataman, 1996).

Generally, they do not have problems with their teachers and with elderly people as they can express themselves well. They easily communicate with their surrounding as they have high self-confidence (Ataman, 1996). However, when they are not perceived in their environment, they might avoid participating in social activities.

Such students are adventurous and willing to take risks as they are curious in nature (Warren and Heist, 1960). Using their leadership abilities, they might lead their friends to situations that their teachers are unwilling. In such cases they might encounter the problem of being called to be the problematic children. They can create troubles when they are not recognized as a result of their self-dependent and persistent behaviors in reaching their goals.

It should be kept in mind that gifted students are those showing extraordinary talent in a certain area and an average talent in other areas or those who excel in language skills but have an average skill in other areas (Gross, 2004; MEB, 2007).

Educating children who have these characteristics is difficult. It is necessary that the teachers of such students must have developed themselves according to the conditions. Although the models used in the education of gifted children are more student-centered, the responsibility of the teacher is more than the responsibilities of teachers in normal educational institutions (Diffily, 2002). In this case, the teachers of such students who are responsible for the education of gifted students must improve themselves personally. Teachers of gifted students set goal for the students, help them to build values, choose teaching methods or strategies and may be most important of all, serve as a model to children (Feldhusen and Wyman-Robinson, 1980). So, the teachers of gifted students must have an education so as to educate them. This, however, is not enough. The school should also provide these opportunities with all its employees. It is highly important that the teachers and administrators know theoretical approaches and their results inside the classroom because extremely optimistic and unrealistic expectations are as destructive as negative attitudes in the education of gifted students. Teachers should have group dynamics skills in a certain issue, use advanced level of technical strategies, should be willing to make research and have the necessary knowledge on computer technology (Rogers, 1989). Learning environment, school administrators and teachers should be compatible with one another.

Recognizing such students in the classroom and making studies for the development of such students have recently been started in Turkey (Öpengin and Sak, 2012; Erişti, 2012). To identify gifted students, Bildiren and Uzun (2007) conducted a study on the different methods. How long the student can concentrate on the course and with which parts of the course the student is interested in is particularly important. It is possible to find out the expectations of these students by getting information from these students and through observations; and provide them with better educational opportunities. In this study, the attention, interest and attitudes of such students are examined and evaluated. For this, the student in this research was wanted to keep science diary throughout four months. Diary is the written answers of teacher or students to teaching/learning business. Keeping a diary serves for two purposes:

1.) Recording the events and ideas for further projections. 2.) The fact that writing process serves to the understanding of the inside story of teaching (Richards, 1995).

By means of an education diary, various issues can be clarified from classroom experiences. Approaching one's own teaching from a critical point of view is a unique feature of keeping a diary and it gives teacher the opportunity to assess his/her own work as a teacher and his/her way of teaching (Richards, 1995).

Also, the teacher observed the behaviors of the student during the course and took notes. The data is obtained through filling the "attitude form" developed by Borich (1999) and translated into Turkish by Selçuk (2001) as well as the list of classroom rules identified by the students.

Çavuş and Özden (2012) researched the views of the primary school students on science diary. They stated that the science diary increased the success of the primary school students.

\section{Purpose}

The purpose of this study is to observe the experiences of a gifted student in a heterogeneous classroom. This student wrote on his diary what he had experienced because of his individual differences and stated that he 
wanted to participate actively in the class activities.

\section{METHODOLOGY}

\section{Research model}

The model of the research is case study. This study is realized with a gifted student in the second grade of an elementary school attached to the Ministry of National Education. This student studied in a regular classroom of an elementary school providing general education without being subjected to a different practice.

\section{Data collection and analysis}

The attitudes of the gifted student inside the classroom were observed by the researcher. The student was also asked to keep a diary of what he experienced during these Science and Technology classes. The student wrote on his diary experiences relating to the days when he took this course. At the end of the semester, the student's diary was collected by the teacher and reviewed. The data is obtained through observations and the notes that the student took. The aim in doing that is to find out what different students experience in the same classroom environment in the educational system. For, while earlier studies on individual differences attributed giftedness to genetic factors, in recent studies it is stated that giftedness occurs as a result of interaction between genetic and environmental factors (Moore, 1992; Thompson and Plomin, 1993). When the diary was examined, the frequency of the student activities which he noted was taken into consideration.

\section{FINDINGS}

\section{Data obtained through student diaries}

The student kept 36 diaries during a semester. The student kept a diary two times a week since he had 4 classes divided into two sessions in a week. The classes were according to the first notes in the diary; the student concentrates on the teacher in the first minutes and tries to do what the teacher asks them to. In 32 diaries among 36 , the student mentions what the teacher says and asks. For instance, in one of the diaries the student wrote: "The teacher came into the classroom, showed us the biscuit in his hand and asked: "how long will it take for me to digest this biscuit in my mouth?" and I said: 'I can finish it in 15 seconds." In the remaining 4 diaries the student wrote his opinions about the activities they were asked to perform. For example, in one of the diaries, the student wrote: "I made the best atomic model that the teacher asked us to. I finished it earlier than the rest of the class and began to examine what my classmates did."

It is seen that the student took notes in the first minutes of the course. He gave clear information about the teacher's engage and his first activities in the classroom. Although the student keeps a diary after he took the course, he could remember what had happened in the first parts of the course. He can give clear information about the first fifteen minutes of the course, and later for the rest of the course, he mentions about activities such as making experiments in which he participates actively.

In all the diaries he wrote what the teacher instructed them to do in the beginning of the course. However, he did not write 14 things that the teacher said at the end of the course.

The student does all the activities assigned completely and properly and he especially shows his work when it is checked. He did all what was said to him in all activity tasks and showed them to his teacher.

From his notes, it is understood that the student is influenced from such visual educational materials as model, picture and slides and that he could maintain his concentration in activities in which he actively takes part. It is seen that the student remembered and wrote all experiments and group games completely. He stated that he wanted to guide the group during the activities and if necessary, do the activity by himself. It was found that the student enjoyed to share what he knew with his friends and wanted to show his friends that he was better than them. For instance, in one of his diaries he wrote: "I know the structure and function of the brain by heart. Thus, I wanted to make the poster of brain by myself. But when the teacher asked me to do it with my friends and tell them what I know, the assignment turned out to be more pleasant. This way, I will show my friends how much I know."

In the subjects which did not attract his attention, he mostly mucked around. The student wrote that he loved to draw and that when he was bored he drew; there were pictures in his diary. This situation is mostly seen when writing the results of the activities. The student finishes his assignment quickly and gets bored when waiting for his friends to finish and thus, he draws. In one of his diaries he wrote: "My friends are too slow in writing the results of the experiment. I am bored when I am waiting them to finish writing. So I drew a car. If only that car was mine and if only it was as fast as neurons."

The student's interest changed according to the course and subject: for instance he was more interested in physics (e.g. electricity) and chemistry (e.g. atom) and was less interested in biology subjects (e.g. systems). In general the student was more interested in subjects that he cannot see with naked eye but can perceive their effects.

In biology subjects he only mentions about visual materials and experiments (e.g. structure of kidneys) while in physics and chemistry subjects, he talks about the things he does not know, the things that he wonder as well as the details of the experiments. For example, he asks such questions as: "How atom turns into bomb?" and "how a new substance is formed by combining two other substances?"

Sometimes the student mentions about the easy questions that his friends asked to the teacher, and he complains about their level. In one of the diaries he says: "Today, a friend of mine asked a very easy question. I sometimes tell myself if I should be friend with those students asking such questions. They are far behind me." 
Table 1. All students' attitudes at certain minutes during the course.

\begin{tabular}{lcccc}
\hline Attitude percentage of students during the course (\%) & \multicolumn{4}{c}{ Minute } \\
\hline Directions & $\mathbf{4}$ & $\mathbf{1 4}$ & $\mathbf{2 4}$ & $\mathbf{3 4}$ \\
\hline Those who certainly are on duty related to the course subject & 59.38 & 37.50 & 40.63 & 31.25 \\
Those who are probably on duty related to the course subject & 15.63 & 31.25 & 28.13 & 25.00 \\
Those who are certainly on duty regarding the course & 12.50 & 21.88 & 15.63 & 21.88 \\
Those who are probably on duty regarding the course & 9.38 & 3.13 & 6.25 & 12.50 \\
Those who are off-duty & 3.13 & 6.25 & 9.38 & 9.38 \\
Those who are in dead time & 0.00 & 0.00 & 0.00 & 0.00 \\
Those who cannot be observed & 0.00 & 0.00 & 0.00 & 0.00 \\
\hline
\end{tabular}

Source: Borich, 1999; Selçuk, 2001.

When the student's interest in the course is assessed, it is observed that he was interested with the subject in the first 15 min but in the rest of the time he was seen to be spending his time with his environment and with what he wrote. In subjects that did not attract his attention, he drew some images and mostly these were car images. It is also considered that as he knew that what he wrote would be read by the teacher, he refrained from writing some silly things.

\section{Data obtained from teacher observation and inspection}

Teacher collected data in two ways. First of all, he filled in the observation forms which he prepared. The second data source was teacher's observations. He filled in the attitude observation form and classroom rules as observation forms. He wrote down what all students did at certain times and what the gifted student did. All students' attitudes at certain minutes during the course are presented in Table 1.

This form was filled for 18 times. According to the forms, it is seen that the student interest towards the course decreased on time. How many students were doing which of the behaviors mentioned in Table 1 in the $4^{\text {th }}$, $14^{\text {th }}, 24^{\text {th }}$ and $34^{\text {th }}$ minutes of the course were identified and their percentages were calculated.

The statements in the form were:

(i) Those who certainly are on duty related to the course subject: Students who are doing an academic assignment, participating in a presentation, engaged in doing a given task carefully.

(ii) Those who are probably on duty related to the course subject: Students who are not certainly off-duty but who are suspected to be on duty. The materials regarding their assignments are on their desks but they are looking at walls, to the window or outside. They could be thinking about their assignments at the moment or daydreaming.

(iii) Those who are certainly on duty regarding the course: The student strives to start or finish a duty. Sharpening a pencil, taking his books and notebooks out of his bag, borrowing book from his friends, writing date or topic to his notebook, lining up for an activity etc.

(iv) Those who are probably on duty regarding the course: They seem to be busy with some activities. They are not totally on duty or off-duty. Students who are moving around the classroom to take something from the cupboard but who do not intentionally head towards doing that could be grouped here.

(v) Those who are off-duty: Students who are obviously doing things that are not allowed, those who speak to their desk mates although the teachers asks them not to do, those who cheat, who play around the classroom in a disorderly manner, those who roll around the classroom although the teacher did not allow them or those students who do not sit on their desks could be grouped here.

(vi) Those who are in dead time: Those students who are doing nothing are included in this group.

(v) Those who cannot be observed: Those students that the teacher cannot observe from where he sits. The students who are not in the classroom are not in this group (Selçuk, 2001).

The activity of the gifted student during the time the teacher was in the classroom was also recorded according to this form. Table 2 shows how often gifted student did an activity at certain minutes.

Data in Table 2 shows that the gifted student was focused on the course at the beginning, however, later his participation declined according to the activity. When this data is compared to the data of the rest of the classroom, the results were found to be similar. This shows us that the gifted student is easily affected from the overall atmosphere of the classroom.

The gifted student is interested in group works. It is found that the student was interested in all nine group activities. It is understood from the observations made that the student was prepared for all group activities and tried to take active role in the planning of the group works. He tried to direct the planning of the activity and take the lead in the group. He also tried to ensure that all his friends took part in the group activity and asked them 
Table 2. Behaviors of gifted student at certain minutes.

\begin{tabular}{lcccc}
\hline Behavior frequency of gifted student during the course & \multicolumn{3}{c}{ Course minute } \\
\hline Directions & $\mathbf{4}$ & $\mathbf{1 4}$ & $\mathbf{2 4}$ & $\mathbf{3 4}$ \\
\hline Times when he certainly was on duty related to the course subject & 16 & 13 & 11 & 8 \\
Times when he probably was on duty related to the course subject & 1 & 3 & 2 & 4 \\
Times when he certainly was on duty regarding the course & 1 & 2 & 3 & 2 \\
Times when he probably was on duty regarding the course & 0 & 0 & 1 & 2 \\
Times when he was off-duty & 0 & 0 & 1 & 2 \\
Times when he was in dead time & 0 & 0 & 0 & 0 \\
Times when he could not be observed & 0 & 0 & 0 & 0 \\
\hline
\end{tabular}

Source: Borich, 1999; Selçuk, 2001.

to participate. He contributed to the activity with his ideas and ensured the continuity of the activities by warning those friends who prevented the flow of the activity.

The observations made showed that gifted student had some problems in following classroom rules. It is seen that generally, since the rest of his friends fell behind in completing some activities, he disturbed his friends in that time. In the observations throughout the term, it is seen that he broke the rule of "not disturbing your friends" for 12 times. And similarly, he broke the rule of "not speaking without taking permission" for 15 times during the term. Apart from these, he did not show such behaviors as leaving the desk without permission and not following the directions of the teacher.

According to the teacher; The student does not interrupt the flow of the course but tries to contribute. He cannot stay focused continually and is bored easily. He is interested in activities in which he can take an active role physically and bored in such activities as writing and reading. He gets high marks from the written examinations but the results change according to the subjects that he is interested in. While he sometimes gets the highest mark in the classroom, he gets an average mark at other times.

In general, the student did not show a negative attitude towards his friends, teachers and the way of teaching the lesson. He cannot keep his interest alive for long. He prefers doing individual homework rather than group works and likes being praised. He feels that he is better than his friends and wants this to be noticed.

\section{SUGGESTIONS}

Gifted students put forth a lot of effort to succeed. The student in this research said that he worked hard to succeed but he could not find the level of pleasure he seeks from the lessons. This student whose graphic has ups and downs begins to internalize the working principles of his friends in the coming years. His words like "I was more successful previously" show that he is not glad with himself in time. Teachers should prepare additional instruction schedules for such students. Additionally, these instruction schedules should not disturb the regular classroom order as well as the comfort of the rest of the students. The classroom level could be quite lower than the level of these gifted students. The classroom teachers should take following points into consideration in order to help for better development of the students;

1. Student work and homework: The teacher should not keep the subjects taught in the classroom at the same level for those students and should give assignments according to the performance and speed of these students. In order to do that; (a) Homework should not include a lot of repetitions and exercises. Excessive repetition affects those students negatively. (b) More homework that includes problem solving technique should be assigned to the gifted student. Such studies support student to tend to work. (c) Homework such as reading and summarizing technical materials, modeling some equipment, drawing charts and explaining their working principles should be given. Studies that are one level above the classroom level attract the attention of these students. For instance, the student in this study expressed: "In the digestive system game that the teacher showed us, I finished the whole steps first. It was very enjoyable. I want to do a similar game now."

2. Extensive observation and experiments should be included in classroom activities. Standard activities displease such students. Aktepe and Aktepe (2009) stated that the teachers who worked at the gifted students' school did not use teaching techniques which were field trips, observations, role-play. Bozdoğan and Yalçin (2006) stated that the instruments and the activities in the Energy Park have a considerable effect on the increase and maintenance of "science interest" of the students and of their academic achievement.

3. Science diary increases the success of the students (Çavuş and Özden, 2012). This type of application should be maintained.

4. Such students should be encouraged to participate in activities that require leading or that will provide an 
opportunity to develop leadership.

5. Teachers should cooperate with the parents of such students and parents should be taught to raise their children without ignoring them. For instance, the child in this study complains about his parents: "when I will be doing this work at home, my father will intervene and say 'why you do this?'. But I want to do this model. No one will believe that I did it". The definition of "gifted student" may adversely affect students. Öpengin and Sak (2012) stated gifted students had less positive perceptions about their friends' attitudes towards them compared to those who were not identified to be "gifted". O'Connor (2012) stated that there is growing evidence that children labelled as academically gifted are subjected to negative attitudes from others and that this impacts on their selfesteem and motivation to succeed.

6. Such courses as drawing, music and physical education should not be ignored for academic purposes. The student wrote in his diary: "If only teachers let us draw such pictures in drawing classes" and "if they told us about our muscles before physical education classes, we would be more successful."

7. The students should be directed for activities inside and outside the school. Activities outside the school could be trekking and science camps.

8. There should be elementary and high schools that are appropriate for the education of such students. Also appropriate programmes for these schools should be prepared (Howley et al., 2012). Aljughaiman and Ayoub (2012) investigated the effects of a school enrichment program on the analytical, creative, and practical abilities of elementary gifted students. They stated that enrichment program ensured analytical, creative, and practical abilities of elementary gifted students.

\section{REFERENCES}

Aljughaiman AM, Ayoub AEA (2012). The effect of an enrichment program on developing analytical, creative, and practical abilities of elementary gifted students. J. Educ. Gift. 35(2):153-174.

Aktepe V, Aktepe L (2009). Teaching method using science and technology education on students' aspects: the example of Kırşehir BILLSEM, Ahi Evran Üniversitesi Kırşehir Eğitim Fakültesi Dergisi (KEFAD), Cilt 10(1):69-80.

Ataman A (1996). Üstün zekalı ve üstün özel yetenekli çocuklar.In: Fındıkçı İ (Ed). Eğitimimize Bakışlar 1, İstanbul: Kültür Koleji Eğitim Vakfı Yayınları.

Bildiren A, Uzun M (2007). An identification study for gifted students, Pamukkale Üniversitesi Eğitim Fakültesi Dergisi 22(2):31-39.

Borich GD (1999). Observation skills for effective teaching. (3th ed). Ohio: Prentice Hall.

Bozdoğan AE, Yalçın N (2006). The effects of science centers on the change of "science interest" levels of primary education students and on their academic success: Energy park. Ege Eğitim Dergisi 7(2):95114.
Culatta RA, Tompkins JR (1999). Fundamentals of Special Education What Every Teacher Needs to Know. New Jersey: PrenticeHallInc. Simon \& Schuster/A Viacom Company.

Çavuş E, Özden M (2012). Primary school students' views about use of science journal in science and technology course.Adıyaman Üniversitesi Fen Bilimleri Dergisi 2(2):34-48.

Çepni S, Gökdere M (2002). Profiles of the Gifted Students in Turkey Education., Changing Times, Changing needs" First international conference on education, Faculty of Education Eastern Mediterranean University Gazimagusa, Turkish Republic of North Cyprus.

Diffily D (2002).Project-Based Learning: Meeting Social Studies Standards and the Needs of Gifted Learners, Gifted Child Today 25(3):40-43.

Erişti B (2012). Gifted students' perceptions about learning, teaching, teacher characteristics and teaching as a profession. Turk. J. Giftedness Educ. 2(1):18-36.

Feldhusen JF, Wyman-Robinson AJ (1980). Super Saturday: Design and Implementation of Purdue's special program for gifted children. Gift. Child Q. 24:15-21.

Gross UM (2004). Exceptionally gifted children. (2nd ed). London: Routledge Falmer.

Gökdere M, Çepni S (2003). Üstün yetenekli öğrencilerin fen öğretmenlerinin eğitimine yönelik bir model önerisi, Turkish Online J. Educ. Technol. 2(3).

Howley M, Howley AA, Helfrich S, Harrison L, Gillam MB, Safran J (2012). A Research-Focused Honors Program for High-Ability Teacher-Education Students. J. Educ. Gift. 35(4):319-343.

Marland (1972). Education of gifted and talented, Washington D.C: US Office of Education.

MEB (2007). Çocuk gelişimi ve eğitimi, üstün zekâ ve özel yetenekli çocuklar. Ankara: MEB.

Moore AD (1992).Gifted and talented children and youth. In: Bullock LM, Heflin J (Eds), Exceptionalities in Children and Youth, U.S.A: Allyn and BaconInc pp.420-449.

O'Connor J (2012). Is it good to be gifted? The social construction of the gifted child. Children Society 26:293-303. DOI: 10.1111/j.10990860.2010 .00341$.

Öpengin E, Sak U (2012). Effects of gifted label on gifted students' perceptions.Turkish J. Giftedness Educ. 2(1):37-59.

Passow AH (1993). National/State Policies Regarding Education of the Gifted. In: Heller KA, Mönks FJ \& Passow AH (Eds.), International Handbook of Research and Development of Giftedness and Talent, Oxford: Pergamon Press pp.29-46.

Renzulli JS, Reis SM (1985). The school wide enrichment model: A comprehensive plan for educational excellence. Mansfield Center,CT: Creative Learning Press.

Renzulli JS (1999). What is thing called Giftedness, and How do we Develop it? A twenty-five year perspective. J. Educ. Gift. 23(1):3-54.

Richards JC (1995). (Ed.). Reflective teaching in second language classrooms.New York: Cambridge University Press.

Rogers KB (1989). Training teachers of gifted: What do they need to know? Roeper Rev. 11(3):145-150.

Selçuk Z (2001). Okul deneyimi ve uygulama (2. Baskı).Ankara:Nobel Yayın Dağıtım.

Thompson LA, Plomin R (1993). Genetic influence on cognitive ability. International handbook of research and development of giftedness and talent.Edited by Kurt A, Heller Franz J, Mönks A. Harry Passow, Oxford: Pergamon Press pp.103-113.

Warren J, Heist PA (1960). Personality Attributes of Gifted College Students. Science 132(3423):330-337. 